\title{
DYSLIPIDEMIA AMONG THE ELDERLY IN SLUMS OF WEST DELHI
}

\section{ZAOZIANLUNGLIU GONMEI ${ }^{1,2}$, SUPRIYA DWIVEDI ${ }^{1,3}$, GURUDAYAL SINGH TOTEJA ${ }^{1,4 *}$, KARUNA SINGH ${ }^{2}$, NAVAL KISHORE VIKRAM ${ }^{5}$, PRIYANKA GUPTA BANSAL ${ }^{1}$, SUMAN RATHORE ${ }^{3}$}

\begin{abstract}
${ }^{1}$ Division of Nutrition, Centre for Promotion of Nutrition Research \& Training with special focus on North East, Tribal \& Inaccessible population (Indian Council of Medical Research), New Delhi, India. ${ }^{2}$ Department of Food \& Nutrition, Amity Institute of Food Technology, Amity University Uttar Pradesh, Noida, Uttar Pradesh, India. ${ }^{3}$ Department of Biotechnology, Amity Institute of Biotechnology, Amity University Uttar Pradesh, Noida, Uttar Pradesh, India. ${ }^{4}$ Desert Medicine Research Centre (Indian Council of Medical Research), Jodhpur,

Rajasthan, India. ${ }^{5}$ Department of Medicine, All India Institute of Medical Sciences, New Delhi, India. Email: gstoteja@gmail.com
\end{abstract}

Received: 30 September 2017, Revised and Accepted: 15 January 2018

\section{ABSTRACT}

Objective: The objective of this study is to assess the prevalence of dyslipidemia among the elderly in slums of West Delhi.

Methods: A cross-sectional study was carried out in slums of West Delhi covering a total of 234 elderly aged 60 and above. $5 \mathrm{ml}$ blood was collected from 103 elderly and was analyzed for serum total cholesterol, triglyceride, high-density lipoprotein (HDL) cholesterol, and low-density lipoprotein (LDL) cholesterol by enzymatic method using fully automatic analyzer (Roche Hitachi-902). Dyslipidemia was defined using the National Cholesterol Education Program, ATP-III guidelines.

Results: The overall prevalence of high cholesterol $(\geq 200 \mathrm{mg} / \mathrm{dl}$ ), high triglyceride ( $\geq 150 \mathrm{mg} / \mathrm{dl}$ ), low HDL cholesterol (male $-<40 \mathrm{mg} / \mathrm{dl}$; female - $<50 \mathrm{mg} / \mathrm{dl}$ ), and high LDL cholesterol ( $\geq 130 \mathrm{mg} / \mathrm{dl}$ ) was $20.39 \%, 45.63 \%, 64.08 \%$, and $17.31 \%$, respectively.

Conclusion: Low HDL cholesterol and high triglyceride were the most form of dyslipidemia among the elderly. Awareness on dietary and lifestyle modification for management of dyslipidemia needs to be imparted.

Keywords: Elderly, Dyslipidemia

(c) 2018 The Authors. Published by Innovare Academic Sciences Pvt Ltd. This is an open access article under the CC BY license (http://creativecommons. org/licenses/by/4. 0/) DOI: http://dx.doi.org/10.22159/ajpcr.2018.v11i2.24034

\section{INTRODUCTION}

Cardiovascular disease (CVD) is one of the five global leading causes of total years of life lost in 2016 [1]. Dyslipidemia is a well-established risk factor of CVD amounting to more than half of the global cases of coronary artery disease [2,3]. Its prevalence has increased over a period of 20 years among the urban population in India [4]. Rapid urbanization, rural-tourban migration, poor dietary habits, physical inactivity, sociocultural factors, and genetic predisposition all contribute to dyslipidemia [5]. The WHO Study on Global Aging and Adult Health carried out among 39,436 adults during 2007-2010 revealed that rural-urban migrants had a similar risk factor profile for non-communicable disease to the urban group, suggesting that exposure to urban environments may promote assimilation of health behavior regardless of previous life experiences [6]. This study was carried out to assess the prevalence of dyslipidemia among the elderly in slums of West Delhi.

\section{METHODS}

A cross-sectional study was carried out in slums of West Delhi. A total of 234 elderly aged 60 and above were enrolled in the study with the help of local community leaders and paramedicals working in the area. $5 \mathrm{ml}$ blood was drawn from 103 elderly and was analyzed for serum total cholesterol, triglyceride, high-density lipoprotein (HDL) cholesterol, and low-density lipoprotein (LDL) cholesterol by enzymatic method using fully automatic analyzer (Roche Hitachi-902). The biochemical analysis was done at the National Accreditation Board for Testing and Calibration Laboratories Accredited Laboratory, Centre for Promotion of Nutrition Research and Training, with a special focus on North-East, Tribal and Inaccessible Population (Indian Council of Medical Research), New Delhi. Internal and external quality control of analysis was maintained. The institutional ethical clearance was obtained. A written informed consent was taken from all the study volunteers.
Dyslipidemia was defined using the National Cholesterol Education Program, ATP-III guidelines [7].

\section{RESULTS}

The overall mean of serum total cholesterol, triglyceride, HDL cholesterol, and LDL cholesterol is $68.86 \mathrm{mg} / \mathrm{dl}, 162.5 \mathrm{mg} / \mathrm{dl}$, $43.89 \mathrm{mg} / \mathrm{dl}$, and $105.6 \mathrm{mg} / \mathrm{dl}$, respectively (Table 1 ). The mean level of all parameters was higher in female as compared to males.

The overall prevalence of high cholesterol $(\geq 200 \mathrm{mg} / \mathrm{dl}$ ), high triglyceride $(\geq 150 \mathrm{mg} / \mathrm{dl}$ ), low HDL cholesterol (male - $<40 \mathrm{mg} / \mathrm{dl}$; female $-<50 \mathrm{mg} / \mathrm{dl}$ ), and high LDL cholesterol ( $\geq 130 \mathrm{mg} / \mathrm{dl}$ ), respectively, was $20.39 \%, 45.63 \%, 64.08 \%$, and $17.31 \%$ (Table 2). Prevalence of dyslipidemia was higher in females compared to male elderly.

\section{DISCUSSION}

Our study indicated overall prevalence of high cholesterol ( $\geq 200 \mathrm{mg} / \mathrm{dl})$, high triglyceride ( $\geq 150 \mathrm{mg} / \mathrm{dl}$ ), low HDL cholesterol (male - $<40 \mathrm{mg} / \mathrm{dl}$; female $-<50 \mathrm{mg} / \mathrm{dl}$ ), and high LDL cholesterol ( $\geq 130 \mathrm{mg} / \mathrm{dl}$ ), respectively, as $20.39 \%, 45.63 \%, 64.08 \%$, and $17.31 \%$. A study carried out in Changsha, China, among 3500 persons aged 65 and over also reported high serum cholesterol, triglyceride, and LDL as $25.31 \%$, 26.54\%, and $16.65 \%$, respectively [8]. Another study carried out among rural elderly in China reported the similar prevalence of high cholesterol (18.13\%), while prevalence of high triglyceride $(12.21 \%)$, low HDL cholesterol (32.76\%), and high LDL cholesterol (13.23\%) was lower compared to our findings [9]. Asian Indians have an abnormal fat distribution which makes it more prone to dyslipidemia [10].

Low HDL cholesterol was the most common among the elderly in our study. The Indian Council of Medical Research-India Diabetes 
Table 1: Mean \pm SD and median serum levels of total cholesterol, triglyceride, HDL cholesterol, and LDL cholesterol of elderly

\begin{tabular}{|c|c|c|c|c|c|c|c|c|c|}
\hline \multirow[t]{2}{*}{ Parameters } & \multirow[t]{2}{*}{$\mathbf{N}$} & \multicolumn{2}{|l|}{ All } & \multirow[t]{2}{*}{$\mathbf{N}$} & \multicolumn{2}{|l|}{ Male } & \multirow[t]{2}{*}{$\mathbf{N}$} & \multicolumn{2}{|l|}{ Female } \\
\hline & & Mean & Median & & Mean & Median & & Mean & Median \\
\hline Total cholesterol (mg/dl) & 103 & 68.86 & 171 & 56 & 162.11 & 163.74 & 47 & 176.89 & 179.29 \\
\hline $\mathrm{HDL}(\mathrm{mg} / \mathrm{dl})$ & 103 & 43.89 & 39.51 & 56 & 41.9 & 41.1 & 47 & 46.23 & 38.15 \\
\hline $\mathrm{LDL}(\mathrm{mg} / \mathrm{dl})$ & 52 & 105.60 & 109.00 & 21 & 96.05 & 98.00 & 31 & 112.06 & 113.00 \\
\hline
\end{tabular}

HDL: High-density lipoprotein, LDL: Low-density lipoprotein

Table 2: Prevalence of dyslipidemia in the elderly

\begin{tabular}{|c|c|c|c|c|c|c|}
\hline \multirow[t]{2}{*}{ Parameters } & \multirow[t]{2}{*}{$\mathbf{N}$} & All & \multirow[t]{2}{*}{$\mathbf{N}$} & Male & \multirow[t]{2}{*}{$\mathbf{N}$} & \multirow{2}{*}{$\begin{array}{l}\text { Female } \\
\mathrm{N}(\%)\end{array}$} \\
\hline & & N (\%) & & N (\%) & & \\
\hline Total cholesterol ( $\geq 200 \mathrm{mg} / \mathrm{dl})$ & 103 & $21(20.39)$ & 56 & $9(16.07)$ & 47 & $12(25.53)$ \\
\hline Triglycerides ( $\geq 150 \mathrm{mg} / \mathrm{dl})$ & 103 & $47(45.63)$ & 56 & $19(33.93)$ & 47 & $28(59.57)$ \\
\hline HDL-cholesterol (M - <40 mg/dl; F - <50 mg/dl) & 103 & $66(64.08)$ & 56 & $27(48.21)$ & 47 & $39(82.98)$ \\
\hline LDL-cholesterol ( $\geq 130 \mathrm{mg} / \mathrm{dl})$ & 52 & $9(17.31)$ & 21 & $2(9.52)$ & 31 & $7(22.58)$ \\
\hline
\end{tabular}

HDL: High-density lipoprotein, LDL: Low-density lipoprotein

study carried out among adults in Tamil Nadu, Maharashtra, Jharkhand, and Chandigarh also reported the prevalence of low HDL cholesterol $(72.3 \%)$ as the most common dyslipidemia compared to hypercholesterolemia (13.9\%), hypertriglyceridemia (29.5\%), and high LDL cholesterol (11.8\%) [11]. A recent survey of the National Nutrition Monitoring Bureau Survey carried out by the Indian Council of Medical Research in urban areas indicated that more than $20 \%$ of adults had total cholesterol $\geq 200 \mathrm{mg} / \mathrm{dl}$ and LDL cholesterol $\geq 130 \mathrm{mg} / \mathrm{dl}$, while around $40 \%$ of men and $28 \%$ of women had triglycerides $\geq 150 \mathrm{mg} / \mathrm{dl}$ and about $74 \%$ of men and $82 \%$ of women had low HDL cholesterol $<40 / 50 \mathrm{mg} / \mathrm{dl}[12]$.

The concentration of cholesterol increases until 45-55 years of age in men, while for women, it continues increasing and only declines in the last decade of life [13]. A cross-sectional study carried out among 5375 adults in China also revealed peak prevalence of dyslipidemia in men between 30 and 39 years with a gradual decline as age increases, while in women, the prevalence of dyslipidemia increased with age and peak prevalence occurs after the age of 60 [14]. Menopause leads to changes in hormonal status and lipid profile in women by resulting in increased total and LDL cholesterol and reduced HDL cholesterol [15]. Our study also revealed a higher prevalence of dyslipidemia among elderly female compared to male. A study carried out among in rural Thailand also reported that women had significantly higher cholesterol and LDL cholesterol levels than men [16].

\section{CONCLUSION}

Low HDL cholesterol and high triglyceride were the most form of dyslipidemia among the elderly. Awareness on dietary and lifestyle modification for management of dyslipidemia needs to be imparted.

\section{ACKNOWLEDGMENT}

The authors acknowledge the support of Indian Council of Medical Research and University Grants Commission.

\section{AUTHORS CONTRIBUTIONS}

- *Zaozianlungliu Gonmei: Data collection, data analysis, interpretation of data, and paper writing

- *Supriya Dwivedi: Data collection, data analysis, interpretation of data, and paper writing

- Dr. Gurudayal Singh Toteja: Conceptualization of study, interpretation of data, and finalization of manuscript

- Dr. Karuna Singh: Conceptualization of study and interpretation of data
- Dr. Naval Kishore Vikram: Conceptualization of study and interpretation of data

- Dr. Priyanka Gupta Bansal: Conceptualization of study and interpretation of data

- Suman Rathore: Interpretation of data.

${ }^{*}$ Equal contribution

\section{CONFLICT OF INTEREST}

The authors declare that there are no conflicts of interest.

\section{REFERENCES}

1. GBD 2016 Causes of Death Collaborators. Global, regional, and national age-sex specific mortality for 264 causes of death, 1980-2016: A systematic analysis for the global burden of disease study 2016 . Lancet 2017;390:1151-210.

2. Shanmugasundaram M, Rough SJ, Alpert JS. Dyslipidemia in the elderly: Should it be treated? Clin Cardiol 2010;33:4-9.

3. Shelke S, Khairnar A, Rathod V, Kalawane Y, Jagtap A. Review on antihyperlipedemia lipophilic drugs and their novel formulation approaches. Int J Pharm Pharm Sci 2017;9:1-8.

4. Gupta R, Rao RS, Misra A, Sharma SK. Recent trends in epidemiology of dyslipidemias in India. Indian Heart J 2017;69:382-92.

5. Misra A, Shrivastava U. Obesity and dyslipidemia in south Asians. Nutrients 2013;5:2708-33.

6. Oyebode O, Pape UJ, Laverty AA, Lee JT, Bhan N, Millett C. Rural, urban and migrant differences in non-communicable disease riskfactors in middle income countries: A cross-sectional study of WHOSAGE data. PLoS One 2015;10:e 0122747.

7. National Cholesterol Education Program. ATP III Guidelines At-AGlance Quick Desk Reference. USA: National Institutes of Health National Heart, Lung, and Blood Institute; 2001.

8. Liu J, Chen Z, Yang F, Chen W, Hu J, Li D. Prevalence and influencing factors of dyslipidemia among the elderly in Changsha: A communitybased study. J Cent South Univ Med Sci 2014;39:797-801.

9. Su L, Gao S, Unverzagt FW, Cheng Y, Hake AM, Xin P, et al. Selenium level and dyslipidemia in rural elderly Chinese. PLoS One 2015;10:e136706.

10. Nayak BS, Bhaktha G. Inconsistent lipid profiles exhibited among the diabetic Asian Indians of India and Trinidad-a comparative study. Int J Pharm Pharm Sci 2016;8:60-3.

11. Joshi SR, Anjana RM, Deepa M, Pradeepa R, Bhansali A, Dhandania $\mathrm{VK}$, et al. Prevalence of dyslipidemia in urban and rural India: The ICMR-INDIAB study. PLoS One 2014;9:e96808.

12. NNMB Technical Report 27. Diet and Nutritional Status of Urban Population in India and Prevalence of Obesity, Hypertension, Diabetes and Hyperlipidemia in Urban men And Women; 2017.

13. Félix-Redondo FJ, Grau M, Fernández-Bergé D. Cholesterol and cardiovascular disease in the elderly. Facts and gaps. Aging Dis 
2013;4:154-69.

14. Qi L, Ding X, Tang W, Li Q, Mao D, Wang Y. Prevalence and risk factors associated with dyslipidemia in Chongqing, China. Int J Environ Res Public Health 2015;12:13455-65.

15. Saha KR, Rahman MM, Paul AR, Das S, Haque S, Jafrin W, Mia AR.
Changes in lipid profile of postmenopausal women. Mymensingh Med J 2013;22:706-11.

16. Yamwong P, Assantachai P, Amornrat A. Prevalence of dyslipidemia in the elderly in rural areas of Thailand. Southeast Asian J Trop Med Public Health 2000;31:158-62. 